\title{
Scleredema type 2 succesfuly treated with intravenous immunoglobulin
}

\section{Zina Kaddioui', Fatima Ezzehra El Fetoiki', Fouzia Hali ${ }^{1}$, Farida Marnissi², Hayat Dehbi Skali', Soumiya Chiheb ${ }^{1}$}

\author{
${ }^{1}$ Dermatology Department, Chu Ibn Rochd, Casablanca, Morroco, ${ }^{2}$ Anatomy Pathology Department, Chu Ibn Rochd, \\ Casablanca, Morroco
}

Corresponding author: Dr. Zina Kaddioui, E-mail: zina.kaddioui@gmail.com

\begin{abstract}
ABSTRAC
Scleredema is a fibromucinous connective tissue disease characterized by symmetric, nonpitting edema and induration that typically begins at the neck and spreads to the face, scalp, shoulders, and trunk. Although the pathogenesis remains elusive, associations with infection, diabetes mellitus, and paraproteinemia have been established. Limited data are available regarding its course and prognosis. In particular, no consensus on the optimal treatment of this disease exists. We report a new observation of scleredema of Buschke associated treated with intravenous imunoglobulin (IVIG).
\end{abstract}

Key words: Scleredema; Immunoglobulin; Gammapathy

\section{INTRODUCTION}

Scleredema is rare sclerodermoid skin disease characterized by symmetrical diffuse woody induration of the upper part of the body owing to thickened dermis and excessive dermal mucin deposition. Scleredema is often associated with underlying etiologies including recent streptococcal infection, monoclonal gammopathy, or diabetes mellitus. Limited data are available regarding its course and prognosis. In particular, no consensus on the optimal treatment of this disease exists, because of its relative rarity coupled with the limited number of case reports along with the lack of randomized controlled trials and poorly understood pathogenesis [1]. We report a case of a patient with scleredema associated with monoclonal gammapathy of Lambda treated with intravenous immunoglobulin (IVIg). On the other hand, acanthosis nigricans $(\mathrm{AN})$, reported in our case, has also been described in the literature associated with scleredema.

\section{CASE REPORT}

A 52-year-old man, presented with a 2-year history of progressive erythema and induration of the face, neck, trunk, back, upper and lower limbs, sparing the extremities. He denied any history of preceding infection or diabetes mellitus. He did not have any other past medical or family history of systemic diseases, chronic infections, malignancies, or genetic diseases. He was a taxi driver, and was not exposed to any indoor or outdoor toxins, chemicals, or radiation. No history of smoking or alcohol use was reported. Physical examination revealed erythema, with infiltrated edema, and induration of the face, neck, upper trunk, back, upper and lower limbs associated with hyperpigmented, papillomatous plaque on his neck, axillae and wrist extension. (Figs. la and lb). There was a significant limitation of neck flexion, extension, and lateral rotation as well as shoulder adduction and internal rotation. The patient denied difficulty swallowing or restricted breathing. A skin biopsy from the upper back revealed dermal thickening with separation of enlarged collagen bundles by Alcian blue positive mucin deposition. An additional biopsy of the hyperpigmented lesions showed epidermal papillomatosis with thickening of the dermis. The clinical and histological findings were consistent with the diagnosis of scleredema and AN (Figs. 2a and 2b).

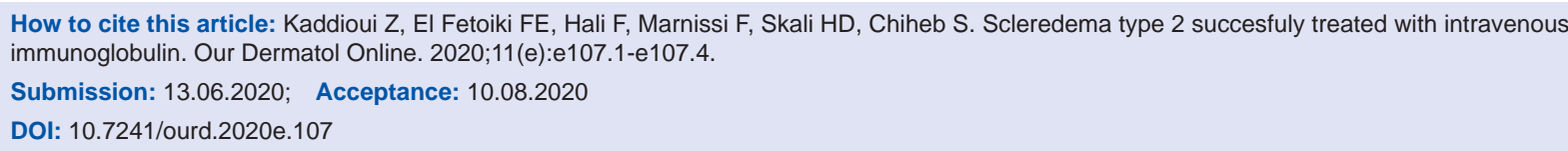




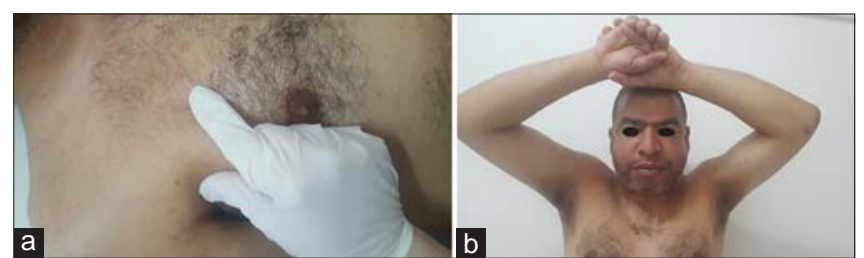

Figure 1: $(a, b)$ Induration of the upper trunk with significant limitation of rang of motion.

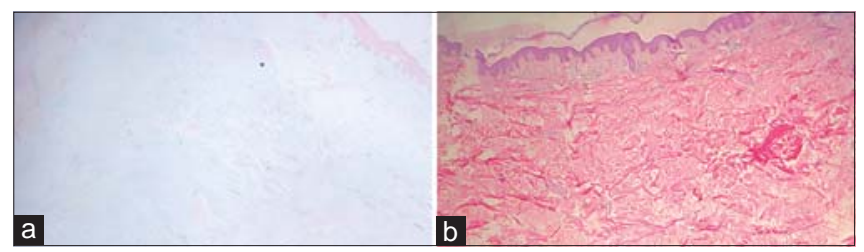

Figure 2: $(a, b)$ Dermal thickening with separation of enlarged collagen bundles by Alcian blue positive mucin deposition.

Findings from a complete metabolic panel, complete blood cell count, and fasting glucose and glycosylated hemoglobin levels were within normal limits. Serum protein electrophoresis revealed an abnormal globulin peak. Immunofixation confirmed an IgG lambda-band. Investigation for multiple myeloma was negative, with normal findings on skeletal survey, bone marrow biopsy, and urine analysis. A diagnosis of scleredema associated with IgG- Lambda paraproteinemia was established.

Patient was put on IVIg range, $2 \mathrm{~g} / \mathrm{kg}$ for 2 consecutive days every 6 weeks for 6 to 8 cycles associated with UVB phototherapy sessions with a slight improvement in skin induration by physician and joints range of motion after his 3rd IVIg course.

The patient continued to receive monthly IVIg therapy with ongoing improvement in skin induration and joints range of motion.

\section{DISCUSSION}

Scleredema, originally described by Buschke in 1902 [2], is a rare sclerodermatosis of unknown etiology, which is characterized by wooden, nonpitting induration of the skin. In general, scleredema first affects the face and neck, and then may spread symmetrically to the shoulders, trunk, arms, and legs, however, the hands and feet are usually unaffected.

Graff [3] described 3 types of scleredema adultorum. Type 1 was the classic type. This type typically has a preceding febrile illness and in most cases resolves completely in several months to 2 years. This type makes up about $55 \%$ of the cases of scleredema adultorum. Type 2 has no preceding febrile illness and no apparent underlying illness. This type tends to follow a slow progressive course with an increased risk of developing paraproteinemias including multiple myeloma. According to AngeliBesson and coworkers [4], type 2 makes up about 25\% of patients. Type 3 has been termed diabetic scleredema by Krakowski and coworkers [5]. This type is a slowly progressive, non resolving scleredema that occurs in diabetic patients. Some have reported a relationship with the level of glucose control, but this is a point of contention [6]. According to Angeli-Besson and coworkers [4], this type makes up about $20 \%$ of cases. Our patient had a type 2 scleredema associated with monoclonal gammapathy made to IgG Lambda.

Korting and coworkers described an association between scleredema adultorum and monoclonal hypergammaglobulinemia in 1974, followed by a similar description from Pajarre [7] in 1975. Angeli-Besson and coworkers [4] reviewed 22 cases and found the onset of hypergammaglobulinemia to be at a younger age than when not associated with scleredema.

The most commonly found immunoglobulins in this review were $\operatorname{IgG}$ and $\operatorname{IgA}$. Four of the 22 patients were noted to have "latent myeloma" with a plasmacytosis of $>10 \%$ in the bone marrow. The monoclonal hypergammaglobulinemia was found several years after the diagnosis of scleredema adultorum. Preceding infection was absent in these patients, increased female:male ratio was noted, and the natural history of the scleredema was longer in those with gammopathy than in those without. Our patient had hypergammaglobulinemia IgG Lambda.

The possible pathology of monoclonal gammopathy and scleredema is still not clear. Kovary et al. suggested that paraproteins may function as anti- bodies directed against connective tissues, but monoclonal immunoglobulins were not detected in the skin by direct immunofluorescence microscopy [8].

$\mathrm{AN}$ is characterized by gray-brown hyperpigmented thickening of flexural or intertriginous regions of the skin resulting in velvety, verrucous plaques. In children, $\mathrm{AN}$ is often benign. In adults it may be associated with endocrinopathies such as hyperinsulinemia, obesity is its most common association, or rarely with malignancies. In a multicenter retrospective study describing clinical features, comorbidities and different therapies in 44 patients, AN was found in 3 patients [1]. 
Table 1 : Cases describing IVIG use in scleredema

\begin{tabular}{|c|c|c|c|c|c|c|c|}
\hline Age & Gender & Diagnosis & Dose & Dose frequency & $\begin{array}{l}\text { Doses to } \\
\text { response }\end{array}$ & $\begin{array}{l}\text { Duration to } \\
\text { response }\end{array}$ & $\begin{array}{l}\text { Adverse } \\
\text { effects }\end{array}$ \\
\hline 38 & $\mathrm{~F}$ & Post streptococcal & $2 \mathrm{~g} / \mathrm{kg}$ over 2 days & 4 weeks & 1 cycle & 10 days & Headache \\
\hline $40 s$ & $\mathrm{~F}$ & $\begin{array}{l}\text { Paraproteinemia } \\
\text { (IGA) }\end{array}$ & $2 \mathrm{~g} / \mathrm{kg}$ over 2 days & Monthly & 2 cycles & 2 months & Not discussed \\
\hline 53 & M & Paraproteinemia (igg) & $2 \mathrm{~g} / \mathrm{kg}$ & Monthly & 4 cycles & 4 months & Not discussed \\
\hline 60 & M & Diabetes & $1.35 \mathrm{~g} / \mathrm{kg}$ given over 3 days & $\begin{array}{l}6 \text { weeks for } 3 \text { cycles folowed } \\
\text { by } 4 \text { months for } 5 \text { cycles }\end{array}$ & 1 cycle & 1 months & Well tolerated \\
\hline
\end{tabular}

Histopathologically, under a spared epidermis, the dermis is three to four times thicker than normal. The collagen fibers appear swollen and are separated by wide spaces in which abnormal deposits of mucin are seen in the reticular dermis. The subcutaneous tissue is also involved with fat being replaced by coarse collagen fibers [9]. Fibroblast proliferation and inflammatory infiltrate are usually absent. Mucin also accumulates in skeletal muscle and the heart, but systemic involvement is not frequent. Extracutaneous complications (in all forms) include serositis, dysarthria, dysphagia, myositis, parotitis, hepatosplenomegaly, and ocular and cardiac manifestations [1]. Our patient had no extracutaneous complications.

As for the treatment of $\mathrm{SAB}$, several options have been tried, including immunosuppressive agents, antibiotics, physiotherapy, thyroid hormones, and systemic glucocorticoids, but no effective treatment has yet been established [10]. Due to the rarity of SAB, randomized controlled trials are difficult, and no first-line therapy has been suggested.

Patients with type $1 \mathrm{SB}$ associated with an underlying infection responded well to treatments with penicillin, UVB, and intravenous immunoglobulin (IVIg). All of these therapies were given in just a few patients, thus we cannot establish them as a standard treatment.

Paraproteinaemias occurring in association with SB are usually therapy-resistant, and the malignant condition must be prioritized. Electron-beam therapy and Extracorporeal photopheresis may be good options. Diabetic scleroderma is the most frequent and, based on our results, we would suggest phototherapy (especially PUVA) or electron-beam therapy as the treatment of choice. In all types of scleroderma, combination therapy may be tried. Adjuvant therapy with penicillin or local therapy with corticosteroids may be worthwhile [11].

Kennemer $\mathrm{C}$ et al report a case of diabetes associated scleredema severe and progressive case treated with
IVIg therapy succesfully [12]. In the literature, there have been four previous cases describing IVIG use in scleredema (Table 1). with good improvement. While the mechanism of action in scleredema treatment is unclear, IVIg seems to be effective irrespective of the underlying cause of the scleredema including gammapathy. Several immunomodulatory mechanisms mediated through either the $\mathrm{Fc}$ or $\mathrm{F}(\mathrm{ab})$ component of the immunoglobulins have been proposed. These include blockade of $\mathrm{Fc}$ receptors on splenic phagocytes, complement pathway inhibition, cytokine modulation, autoantibody neutralization, apoptosis inhibition, dendritic cell modulation, and signaling through the inhibitory Fc receptor Fcgamma RIIb receptor [13].

However, IVIG therapy will need to be tested in larger numbers of patients to elicit more data regarding optimal dosing, frequency of cycles, treatment duration, possible decreasing frequency of cycles, and potential adverse events in treatment of scleredema.

\section{Consent}

The examination of the patient was conducted according to the principles of the Declaration of Helsinki.

The authors certify that they have obtained all appropriate patient consent forms, in which the patients have given consent for images and other clinical information to be included in the journal. The patients understand that their names and initials will not be published and due effort will be made to conceal their identity, but that anonymity cannot be guaranteed.

\section{REFERENCES}

1. Rongioletti F, Kaiser F, Cinotti E, Metze D, Battistella M, CalzavaraPinton PG, et al. Scleredema: a multicentre study of characteristics, comorbidities, course and therapy in 44 patients. J Eur Acad Dermatol Venereol. 2015;29:2399-404.

2. Buschke A. Ueber scleroedem. Berl Klin Wochenschr. 1902;39:955-7.

3. Graff R. Discussion of scleredema adultorum. Arch Dermatol. 1968;98:319-20.

4. Angeli-Besson C, Koeppel MC, Jaquet P, Andrac L, Sayag J. Electronbeam therapy in scleredema adultorum with associated monoclonal hypergamma-blobulinemia. Br J Dermatol. 1994;130:394-7.

5. Krakowski A, Covo J, Berlin C. Diabetic scleredema. Dermatologica. 
www.odermatol.com

1973;146:193-8.

6. Venencie PY, Powell FC, Su WPD, Perry HO. Scleredema: a review of thirty-three cases. J Am Acad Dermatol. 1984;11:128-34.

7. Pajarre S. Scleredema adultorum of Buschke. Acta Derm Venereol. 1975;55:158-9.

8. Kovary PM, Vakilzadeh F, Macher E, Zaun H, Merk H, Goerz G. Monoclonal gammopathy in scleredema: observations in three cases. Arch Dermatol. 1981;117:536-9.

9. Hosthota A, Kothottil R, Subraya SH. Scleredema adultorum of Buschke in a child confi rmed by special stains. Our Dermatol Online. 2018;9:103-4.

10. Miguel D, Schliemann S, Elsned P. Treatment of scleroedema adultorum buschke: a systematic review. Acta Derm Venereol. 2018;98:305-9.

11. Kennemer C, Pavlidakey P, Sami N. Successful treatment with IVIg therapy of diabetes-associated scleredema severe progressive case and review of the literature. Dermatol Ther. 2017;e12504.

12. Kennemer C, Pavlidakey P, Sami N. Successful treatment with IVIg therapy of diabetes-associated scleredema severe progressive case and review of the literature. Dermatol Ther. 2017; 12504.

13. Agonso BAF, Joao CM. The production processes and biological effect of intravenous immunoglobulin. Bio Molec. 2016;6:15-34.

Copyright by Zina Kaddioui, et al. This is an open access article distributed under the terms of the Creative Commons Attribution License, which permits unrestricted use, distribution, and reproduction in any medium, provided the original author and source are credited.

Source of Support: Nil, Conflict of Interest: None declared. 